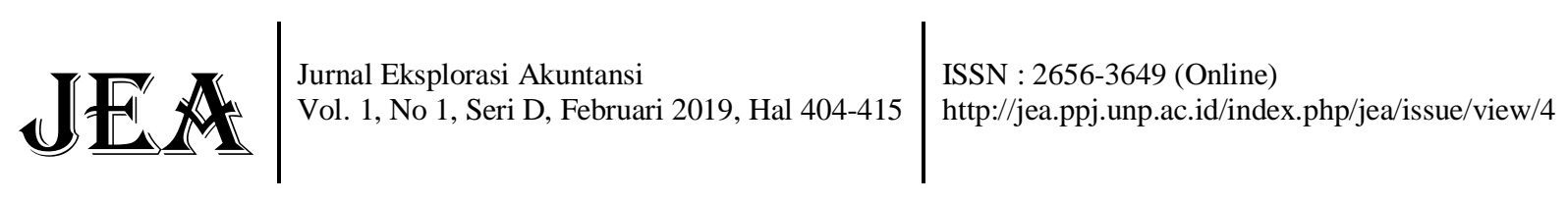

\title{
PENGARUH FINANCIAL LEVERAGE, PROFITABILITAS DAN BESARAN PENAWARAN SAHAM TERHADAP INITIAL RETURN
}

\author{
Darpius $^{1}$, Henri Agustin', Vita Fitria Sari ${ }^{3}$ \\ 1)Alumni Jurusan Akuntansi Fakultas Ekonomi Universitas Negeri Padang \\ 2,3) Jurusan Akuntansi Fakultas Ekonomi Universitas Negeri Padang \\ *Korespondensi: darpius110494@gmail.com
}

\begin{abstract}
This research aimed to give evidence about influence of financial leverage, profitability, and percentage of share which initial return IPO in Indonesia Stock Exchange in the year 2011-2017. Population used in this research is companies that go public on the Indonesia Stock Exchange by taking a sample of firms in 2011-2017, while the sample is 127 companies, with a purposive sampling technique. Type of data used are secondary data. Data collection method used is documentation from www.idx.com and companies website. Analysis tool used is multiple linear regression. The results of this study are (1) financial leverage have significant positive to company's stock initial return (2) profitability and percentage of share has no effect to the company's stock initial return.
\end{abstract}

Keywords: Initial Return; Financial Leverage; Profitability; Percentage of Share

How to cite (APA $6^{\text {th }}$ style)

Darpius, Agustin, H \& Sari, V. F. (2019). Pengaruh Financial Leverage, Profitabilitas dan Besaran Penawaran Saham Terhadap Initial Return. Jurnal Eksplorasi Akuntansi, 1(1) Seri D, 404-415.

\section{PENDAHULUAN}

Dalam menjalankan aktivitas operasionalnya perusahaan pastinya memerlukan kebutuhan dana yang besar untuk pembiayaannya. Akan tetapi terdapat berbagai alternative sumber pendanaan, baik yang berasal dari dalam, umumnya dengan menggunakan laba yang ditahan oleh perusahaan. Sedangkan alternative pendanaan dari luar perusahaan dapat berasal dari kreditur berupa hutang, pembiayaan bentuk lain atau dengan mekanisme penyertaan umunya dilakukan dengan menjual saham perusahaan kepada masyarakat umum atau sering dikenal dengan go public.

Initial Public Offering (IPO) adalah salah satu jalan alternatif pendanaan melalui peningkatan ekuitas dengan cara menawarkan efeknya (saham, obligasi, surat-surat berharga lainnya) kepada publik. IPO secara financial merupakan cara untuk memperoleh modal guna pengembangan bisnis perusahaan dan sarana lainnya sebagai ukuran bahwa perusahaan tersebut telah menjalankan keterbukaan dalam pengelolaan perusahaan yang dampaknya memperoleh citra perusahaan. 
Initial return adalah keuntugan yang didapat pemegang saham karena perbedaan harga saham yang dibeli di pasar perdana dengan harga jual saham yang bersangkutan di pasar sekunder (Kusuma dalam Chairani, 2001). Initial return akan menyebabkan kondisi yang dikenal dengan underpricing dan overpricing. Apabila penentuan harga pada saat IPO lebih rendah dari harga yang terjadi di pasar sekunder di hari pertama, maka akan terjadi underpricing. Tabel 1 di bawah ini berisi informasi daftar initial return yang dialami oleh perusahaan yang melakukan initial public offering (IPO) di bursa efek Indonesia (BEI) dari tahun 2011 sampai tahun 2017:

\section{Tabel 1}

Perkembangan IPO tahun 2011-2017

\begin{tabular}{|c|c|c|c|c|c|c|c|}
\hline $\begin{array}{c}\text { Tahun } \\
\text { IPO }\end{array}$ & $\begin{array}{c}\text { Jumlah } \\
\text { Emiten }\end{array}$ & $\begin{array}{c}\text { Under- } \\
\text { pricing }\end{array}$ & $\begin{array}{c}\text { Rata-rata } \\
\text { nilai } \\
\text { underpricing }\end{array}$ & $\begin{array}{c}\text { Over- } \\
\text { pricing }\end{array}$ & $\begin{array}{c}\text { Rata }- \\
\text { rata nilai } \\
\text { overpricing }\end{array}$ & $\begin{array}{c}\text { Initial } \\
\text { return } \\
\text { tetap } \\
\text { atau 0 }\end{array}$ & $\begin{array}{c}\text { Data } \\
\text { prospektus } \\
\text { tidak } \\
\text { didapat }\end{array}$ \\
\hline 2011 & 25 & 15 & $19 \%$ & 9 & $-15 \%$ & - & 1 \\
\hline 2012 & 22 & 17 & $23 \%$ & 3 & $-25 \%$ & 1 & 1 \\
\hline 2013 & 30 & 22 & $23 \%$ & 6 & $-7 \%$ & 1 & 1 \\
\hline 2014 & 23 & 20 & $30 \%$ & 1 & $-13 \%$ & 1 & 1 \\
\hline 2015 & 16 & 12 & $31 \%$ & - & - & 1 & 3 \\
\hline 2016 & 15 & 13 & $23 \%$ & 2 & $-18.6 \%$ & - & - \\
\hline 2017 & 37 & 24 & $46 \%$ & 7 & $-32 \%$ & - & 6 \\
\hline Jumlah & $\mathbf{1 6 8}$ & $\mathbf{1 2 3}$ & & $\mathbf{2 8}$ & & $\mathbf{4}$ & $\mathbf{1 3}$ \\
\hline
\end{tabular}

Sumber: data diolah 2016

Tabel 1 di atas memperlihatkan jumlah perusahaan atau emiten yang melakukan IPO pada tahun 2011-2017 terdiri atas 168 perusahaan. Dapat diketahui bahwa dari seluruh perusahaan yang melakukan IPO tersebut terdapat 123 perusahaan yang mengalami underpricing dan 23 perusahaan yang mengalami overpricing. Nilai rata-rata underpricing pada tahun 2011 sebesar 19\%, tahun 2012 sebesar 23\%, tahun 2013 sebesar 23\%, tahun 2014 sebesar 30\%, tahun 2015 sebesar 31\%, tahun 2016 sebesar 23\% dan tahun 2017 sebesar 26\%. Dan nilai rata-rata overpricing pada tahun 2011 sebesar -15\%, tahun 2012 sebesar -25\%, tahun 2013 sebesar -7\%, tahun 2014 sebesar - 13\%, tahun 2015 sebesar 0\%, tahun 2016 sebesar $-18.6 \%$ dan tahun 2017 sebesar $-32 \%$.

Data pada tabel 1 membuktikan bahwa banyak perusahaan yang masih kurang efisien dalam memperoleh dana atas penjualan saham perdana mereka. Fenomena initial return terjadi di berbagai pasar modal di seluruh dunia karena adanya asimetri informasi. Asimetri informasi bisa terjadi antara emiten dan underwriter, maupun antara investor. Untuk mengurangi adanya asimetri informasi maka perusahaan akan menerbitkan prospektus, yang berisi informasi dari perusahaan yang berrsangkutan. Informasi yang tercantum dalam prospektus terdiri dari informasi yang sifatnya keuangan dan non keuangan.

Menurut Subramayam (2005), semakin besar proporsi hutang pada struktur modal suatu perusahaan maka semakin tinggi beban tetap dan komitmen pembayaran kembali yang ditimbulkan . Peluang perusahaan tidak mampu membayar bunga dan pokok pinjaman saat jatuh tempo dan kemungkinan yang terburuk, yakni gagal bayar juga meningkat. Semakin besar nilai leverage menggambarkan jika struktur permodalan usaha lebih banyak memanfaatkan hutanghutang relatif terhadap ekuitas. Semakin besar debt to equity ratio (leverage) mencerminkan 
resiko perusahaan yang relatif tinggi, akibatnya para investor cenderung menghindari sahamsaham yang memiliki nilai DER (leverage) yang tinggi.

Profitabilitas diduga ikut mempengaruhi tingkat initial return pada saham perdana. Hal ini dikarenakan profitabilitas memberikan informasi kepada pihak luar mengenai efektifitas operasional perusahaan. Return on Asset (ROA) adalah salah satu cara umtuk mengukur tingkat profitabilitas perusahaan yakni dengan menunjukkan seberapa tepatnya tindakan perusahaan dalam beroperasi atau memanfaatkan aset yang dimilikinya hingga menghasilkan keuntungan atau laba yang lebih tinggi, dengan profitabilitas yang tinggi akan menarik lebih banyak investor untuk melakukan investasi sehingga permintaan akan saham perusahaan akan meningkat.

Besaran penawaran saham adalah jumlah saham yang ditawarkan kepada publik. Jumlah saham yang ditawarkan kepada publik menunjukan berapa besar bagian dari modal disetor yang akan dimiliki oleh publik, semakin besar jumlah saham yang ditawarkan akan semakin memiliki potensi untuk likuidnya perdagangan saham tersebut di bursa (Darmadji, 2012)

Rumusan masalah dari penelitian ini berdasarkan latar belakang di atas, yaitu (1) sejauhmana Financial Leverage mempengaruhi Initial Return pada perusahaan yang melakukan IPO di BEI selama periode 2011-2017, (2) sejauhmana Profitabilitas mempengaruhi Initial Return pada perusahaan yang melakukan IPO di BEI selama periode 2011-2017, dan (3) sejauhmana Besaran Penawaran Saham mempengaruhi Initial Return pada perusahaan yang melakukan IPO di BEI selama periode 2011-2017?

\section{REVIU LITERATUR DAN PENGEMBANGAN HIPOTESIS Teori Signalling}

Signalling theory adalah informasi mengenai perusahaan yang memberikan sinyal bagi investor, dalam keputusan berinvestasi. Sinyal tersebut dapat berupa informasi yang bersifat keuangan dan non keuangan yang menyebutkan bahwa perusahaan tersebut lebih baik daripada perusahaan lain. Investor yang akan berinvestasi pada pasar modal pasti akan melakukan analisa terlebih dahulu sebelum membuat keputusan investasi.

\section{Initial Public Offering (IPO)}

Initial Public Offering (IPO) merupakan kegiatan penawaran umum penjualan saham atau efek lainnya (obligasi, right, warrant) di pasar perdana. Transaksi penawaran umum pertama kalinya ditawarkan di pasar perdana (primary market), selanjutnya saham diperjualbelikan dalam bursa efek yaitu di pasar sekunder (secondary market).

\section{Initial Return}

Menurut Tandelilin (2001), return adalah harapan keuntungan dimasa datang akan investasi yang dilakukan. Return merupakan satu faktor yang memotivasi agar investor berinvestasi. Tandelilin (2001), membagi sumber-sumber return investasi menjadi dua komponen utama, yaitu yield dan capital gain/loss

\section{Financial Leverage}

Rasio ini menggambarkan hubungan antara utang perusahaan terhadap modal maupun asset. Rasio ini memberikan informasi seberapa jauh perusahaan dibiayai oleh utang atau pihak luar dengan kemampuan perusahaan yang digambarkan oleh modal (equity). Perusahaan yang baik sepatutnya memiliki komposisi modal yang lebih besar daripada utang. Rasio ini bisa juga dianggap bagian dari rasio solvabilitas (Harahap, 2010). 


\section{Profitabilitas}

Profitabilitas memberikan informasi seberapa efektif kinerja manajemen secara keseluruhan yang ditunjukan oleh besar kecilnya tingkat laba yang diperoleh dalam hubungannya dengan penjualan maupun investasi. Semakin bagus rasio profitabilitas maka semakin baik pula kemampuan dalam menggambarkan tingginya perolehan keuntungan perusahaan. Profitabilitas sendiri merupakan hasil akhir bersih seberapa baik berbagai kebijakan dan keputusan. Profitabilitas menunjukan seberapa baik perusahaan telah beroperasi sebelum periode itu.

\section{Besaran Penawaran Saham}

Besaran penawaran saham merupakan banyak jumlah saham yang ditawarkan oleh perusahaan kepada publik. Hal tersebut mengindikasikan seberapa besar porsi kepemilikan yang akan dikuasai oleh publik. Semakin besar saham yang ditawarkan kepada publik maka akan semakin sedikit informasi perusahaan yang bersifat privasi. Dengan begitu para investor akan lebih banyak mendapatkan informasi tentang perusahaan sehingga akan mengurangi ketidakpastian kepada perusahaan dan pada akhirnya akan mengurangi underpricing. implikasinya dapat disimpulkan jika semakin besar persentase penawaran saham yang ditawarkan kepada publik akan berdampak pada semakin kecilnya underpricing yang terjadi pada perusahaan tersebut.

\section{Hubungan antara Financial Leverage terhadap Initial Return}

Menurut Subramanyam (2005), bagi investor saham biasa, utang mencerminkan resiko kerugian investasi namun diimbangi dengan potensi keuntungan dan leverage keuangan. Tingkat leverage mempengaruhi keputusan investasi di pasar modal Indonesia, semakin tinggi tingkat leverage suatu perusahaan maka akan semakin tinggi pula resiko yang diterima perusahaan apabila terdapat kemungkinan gagal bayar dari perusahaan untuk menambal hutang-hutangnya yang berpengaruh negative terhadap keputusan investasi di pasar perdana

$\mathbf{H}_{1}$ : Financial Leverage berpengaruh positif terhadap pengungkapan Initial Return

\section{Hubungan antara Profitabilitas terhadap Initial Return}

Return on asset (ROA) dipakai untuk mengukur ketepatan perusahaan dalam menghasilkan laba dengan cara memanfaatkan aset yang dimilikinya. Nilai profitabilitas yang semakin tinggi akan menunjukan bahwa perusahaan mampu menghasilkan laba dimasa datang dan laba merupakan informasi yang penting bagi investor sebagai bahan pertimbangan dalam menanamkan modalnya.

Dengan tingginya nilai profitabilitas diharapkan tingkat initial return dapat diminimalisir, karena penjamin emisi yakin untuk menjual harga saham perusahaan dengan harga yang tinggi dan berekspektasi semua saham yang ditawarkan akan terjual. Profitabilitas yang tinggi akan mengurangi ketidakpastian bagi investor sehingga akan menurunkan tingkat underpricing (Ghozali, 2002 dalam Liza, 2013).

$\mathbf{H}_{2}$ : Profitabilitas berpengaruh negatif terhadap Initial Return.

\section{Hubungan antara Besaran Penawaran Saham terhadap Initial Return.}

Besaran penawaran saham mengindikasikan banyaknya jumlah saham yang ditawarkan oleh perusahaan kepada publik. Dengan kata lain itu menunjukan seberapa besar porsi kepemilikan yang akan dikuasai oleh publik. Informasi ini biasanya dapat ditemukan dalam prospektus yang dikeluarkan perusahaan pada saat IPO. Berdasarkan signaling theory Informasi mengenai berapa banyak saham yang akan dijual ketika IPO memberikan sinyal dalam bentuk 
informasi kepada investor sebagai dasar pertimbangan dalam berinvestasi, dikarenakan semakin besar jumlah yang ditawarkan kepada publik maka akan semakin sedikit informasi yang dirahasiakan perusahaan. Semakin sedikit informasi yang dirahasiakan perusahaan, diharapkan para investor akan mendapat lebih banyak informasi tentang perusahaan sehingga akan mengurangi ketidakpastian terhadap perusahaan dan pada akhirnya akan mengurangi underpricing

$\mathbf{H}_{3}$ : Besaran Penawaran Saham berpengaruh negative terhadap Initial Return.

Variabel Independen $(\mathrm{X})$

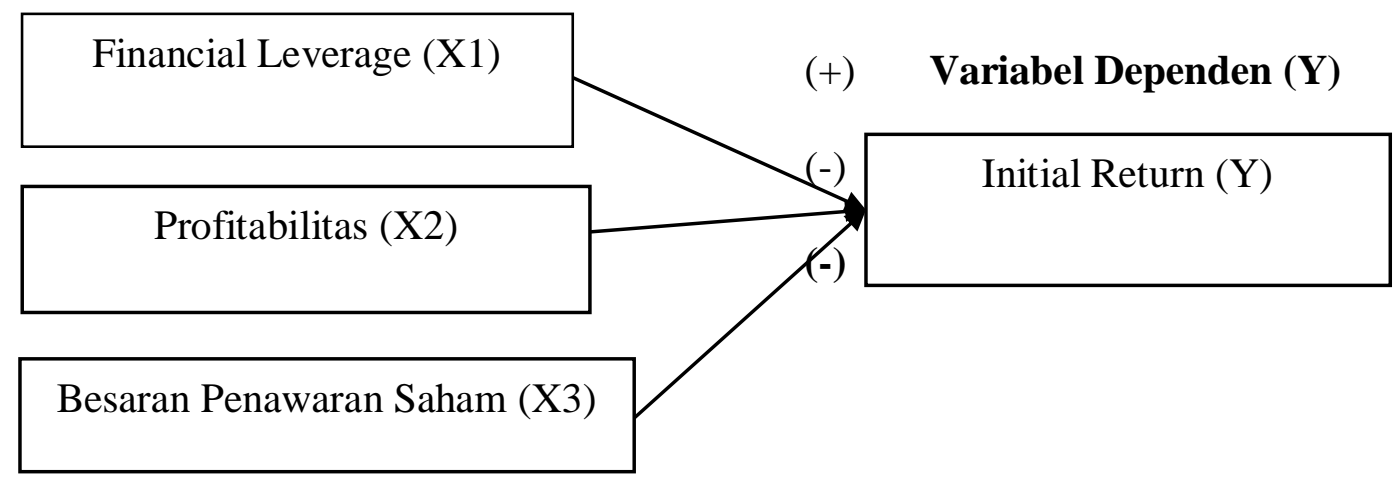

\section{Gambar 1 . Kerangka Konseptual}

\section{METODE PENELITIAN}

Penelitian ini merupakan penelitian kausatif yakni penelitian yang bertujuan untuk menganalisis pengaruh beberapa variabel terhadap variabel lainnya. Penelitian ini menjelaskan pengaruh financial leverage (X1), profitabilitas (X2), dan besaran penawaran saham (X3) sebagai variabel independen terhadap initial return (Y) pada perusahaan yang IPO di BEI pada tahun 2011-2017. Populasi dalam penelitian ini adalah pada seluruh perusahaan yang IPO di Bursa Efek Indonesia periode 2011-2017 dengan menggunakan teknik purposive sampling.

Teknik pengumpulan data yang digunakan adalah teknik observasi dokumentasi dengan mencari informasi atau data yang dibutuhkan di dalam prospektus perusahaan sampel yang diterbitkan oleh perusahaan sampel pada saat IPO. Data diperoleh dari situs resmi Bursa Efek Indonesia (www.idx.co.id), situs resmi perusahaan sampel, dan situs terkait lainnya. Data dianalisis dengan melakukan uji asumsi klasik dan uji regresi berganda dengan bantuan program Eviews7. Model penelitian ini sebagai berikut:

$$
Y=a+b_{1} x_{1}-b_{2} x_{2}-b_{3} x_{3}+e
$$

Dimana:

$$
\begin{array}{ll}
\mathrm{Y} & =\text { initial return } \\
\mathrm{a} & =\text { konstanta } \\
\mathrm{b} 1 \mathrm{~b} 2 \mathrm{~b} 3 & =\text { koefisien regresi dari setiap variabel independen } \\
\mathrm{X}_{1} & =\text { financial leverage } \\
\mathrm{X}_{2} & =\text { profitabilitas } \\
\mathrm{X}_{3} & =\text { besaran penawaran saham }
\end{array}
$$




\section{HASIL DAN PEMBAHASAN}

\section{Gambaran Umum dan Objek Penelitian}

Populasi di dalam penelitian ini adalah seluruh perusahaan yang IPO di Bursa Efek Indonesia selama periode 2011 sampai 2017. Dengan menggunakan metode purposive sampling, maka diperoleh 127 perusahaan yang memenuhi syarat untuk dijadikan sampel.

Penelitian ini menggunakan statistik deskriptif, untuk memberikan gambaran tentang masing-masing variabel yang akan diteliti. Pada table 2 dijelaskan deskriptif variabel-variabel dalam penelitian ini. Variabel initial return bernilai rata-rata 0.196 atau 20\% dengan standar deviasi 0.23999. Initial return tertinggi dengan nilai 0.70 atau $70 \%$ dan terendah -0.29 atau $-29 \%$. Variabel financial leverage bernilai rata-rata sebesar 2.2291 dengan standar deviasi 2.44961 . Nilai financial leverage tertinggi adalah 16.33 dan terendah 0.05 . Variabel profitabilitas bernilai rata-rata sebesar 0.06493 dengan standar deviasi 0.06924 . Nilai profitabilitas tertinggi adalah 0.50 dan terendah adalah -0.001 . Variabel besaran penawaran saham bernilai rata-rata sebesar 0.23126 dengan standar deviasi 0.10794 . Nilai tertinggi adalah 0.70 dan terendah adalah 0.01

Tabel 2

Statistik Deskriptif

\begin{tabular}{lcccc}
\hline & $\mathrm{X} 1$ & $\mathrm{X} 2$ & $\mathrm{X} 3$ & $\mathrm{Y}$ \\
\hline Mean & 2.22921 & 0.06493 & 0.23126 & 0.196 \\
Median & 1.27 & 0.05 & 0.21 & 0.11 \\
Maximum & 16.33 & 0.5 & 0.7 & 0.7 \\
Minimum & 0.05 & 0 & 0.01 & -0.29 \\
Std. Dev. & 2.44961 & 0.06924 & 0.10794 & 0.23999 \\
Skewness & 2.39672 & 2.5327 & 1.3155 & 0.58694 \\
Kurtosis & 11.2382 & 14.2606 & 5.88532 & 2.37635 \\
Jarque-Bera & 480.718 & 806.759 & 80.683 & 9.35007 \\
Probability & 0 & 0 & 0 & 0.00933 \\
Sum & 283.11 & 8.246 & 29.37 & 24.333 \\
Sum Sq. Dev. & 756.076 & 0.60401 & 1.468 & 7.25715 \\
Observations & 127 & 127 & 127 & 127 \\
\hline
\end{tabular}

Sumber: Data Sekunder Olahan Eviews7 2016

Tabel 3. Hasil Uji Normalitas

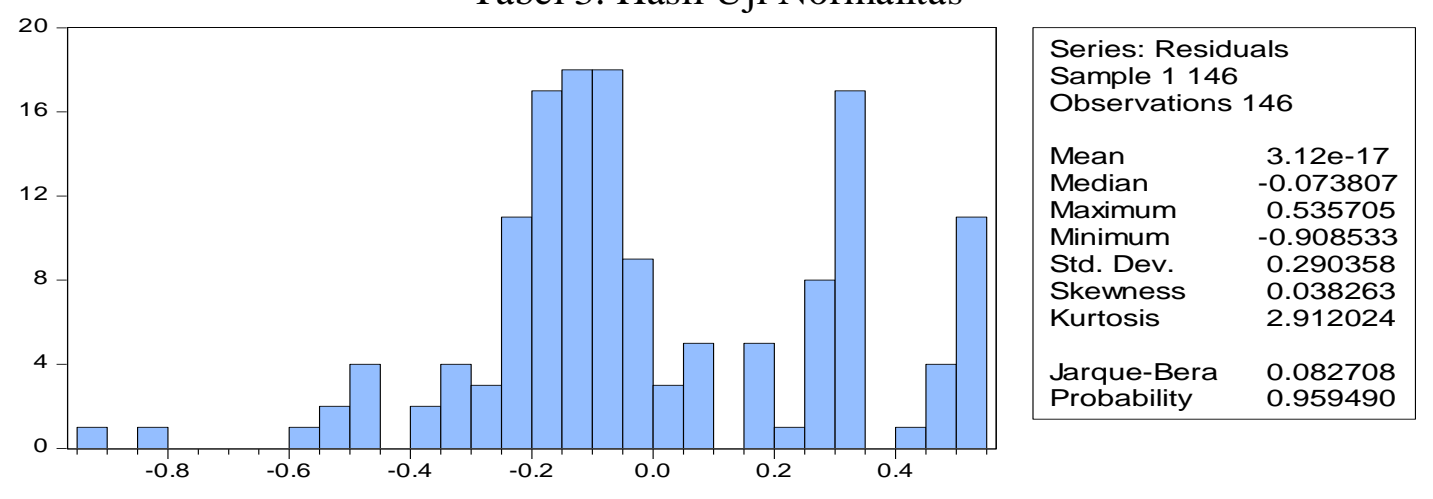


Dari gambar diatas dapat ditarik kesimpulan bahwa data sudah terdistribusi dengan normal. Hal ini dibuktikan dengan nilai probabilitas sebesar 0.959490 Berarti data residual ini sudah terdistribusi secara normal dikarenakan nilai probabilitas $>0.05$. Dari tabel diatas nampak bahwa seluruh variabel bebas memiliki nilai korelasi yang lebih kecil dari 0.8, sehingga dapat ditarik kesimpulan bahwa variabel-variabel pada penelitian ini tidak memiliki masalah kolinearitas yang tidak berarti atau tidak memiliki masalah multikolinearitas. Tolerance diatas 0,1 dan VIF $<10$, jadi dapat disimpulkan bahwa tidak terdapat gejala multikolinearitas antar variabel independen.

Heteroskedasticity Test: White

\begin{tabular}{llll}
\hline \hline F-statistic & 1.245487 & Prob. F(9,117) & 0.2744 \\
Obs*R-squared & 11.10365 & Prob. Chi-Square(9) & 0.2687 \\
Scaled explained SS & 6.211578 & Prob. Chi-Square(9) & 0.7186 \\
\hline \hline
\end{tabular}

Test Equation:

Dependent Variable: RESID^2

Method: Least Squares

Date: 01/30/19 Time: 23:24

Sample: 1127

Included observations: 127

\begin{tabular}{|c|c|c|c|c|}
\hline Variable & Coefficient & Std. Error & t-Statistic & Prob. \\
\hline C & 0.080546 & 0.041013 & 1.963929 & 0.0519 \\
\hline $\mathrm{X} 1$ & 0.001956 & 0.008466 & 0.231011 & 0.8177 \\
\hline$X 1^{\wedge} 2$ & -0.000259 & 0.000441 & -0.587230 & 0.5582 \\
\hline$X 1 * x 2$ & -0.014964 & 0.063517 & -0.235594 & 0.8142 \\
\hline$X 1 * x 3$ & 0.009312 & 0.021208 & 0.439061 & 0.6614 \\
\hline $\mathrm{x} 2$ & -0.519823 & 0.393936 & -1.319561 & 0.1896 \\
\hline$X 2^{\wedge} 2$ & 0.685279 & 0.608173 & 1.126783 & 0.2621 \\
\hline$X 2 * X 3$ & 0.903637 & 1.394754 & 0.647882 & 0.5183 \\
\hline X3 & -0.114586 & 0.232732 & -0.492352 & 0.6234 \\
\hline$X 3^{\wedge} 2$ & 0.154714 & 0.312174 & 0.495601 & 0.6211 \\
\hline R-squared & 0.087430 & \multicolumn{2}{|c|}{ Mean dependent va } & 0.053223 \\
\hline Adjusted R-squared & 0.017233 & \multicolumn{2}{|c|}{ S.D. dependent var } & 0.058358 \\
\hline S.E. of regression & 0.057853 & \multicolumn{2}{|c|}{ Akaike info criterion } & -2.786351 \\
\hline Sum squared resid & 0.391597 & \multicolumn{2}{|c|}{ Schwarz criterion } & -2.562399 \\
\hline Log likelihood & 186.9333 & \multicolumn{2}{|c|}{ Hannan-Quinn criter. } & -2.695362 \\
\hline F-statistic & 1.245487 & \multicolumn{2}{|c|}{ Durbin-Watson stat } & 1.857112 \\
\hline Prob(F-statistic) & 0.274357 & & & \\
\hline
\end{tabular}

Pada tabel diatas, diketahui nilai sig 0.8177 untuk financial leverage (X1), sig 0.1896 untuk profitabilitas (X2) dan sig 0.6234 untuk besaran penawaran saham (X3). Ketiga nilai sig dari variabel tersebut $>$ dari 0.05 , maka dapat disimpulkan bahwa tidak terjadi gejala heteroskedastisitas pada model regresi ini. 
Dependent Variable: $Y$

\section{Tabel 7 \\ Uji Linear Regresi Berganda}

Method: Least Squares

Date: 01/30/19 Time: 23:08

Sample (adjusted): 1127

Included observations: 127 after adjustments

\begin{tabular}{lrllr}
\hline \hline \multicolumn{1}{c}{ Variable } & Coefficient & Std. Error & t-Statistic & Prob. \\
\hline \hline C & 0.196381 & 0.063947 & 3.071005 & 0.0026 \\
X1 & 0.023385 & 0.008781 & 2.663086 & 0.0088 \\
X2 & -0.194305 & 0.321605 & -0.604174 & 0.5468 \\
X3 & -0.191546 & 0.200747 & -0.954163 & 0.3419 \\
\hline \hline R-squared & 0.068589 & Mean dependent var & 0.191598 \\
Adjusted R-squared & 0.045872 & S.D. dependent var & 0.239992 \\
S.E. of regression & 0.234423 & Akaike info criterion & -0.032386 \\
Sum squared resid & 6.759382 & Schwarz criterion & 0.057194 \\
Log likelihood & 6.056539 & Hannan-Quinn criter. & 0.004009 \\
F-statistic & 3.019251 & Durbin-Watson stat & 1.889905 \\
Prob(F-statistic) & 0.032437 & & \\
\hline \hline
\end{tabular}

Sumber: Hasil olahan Eviews 7 tahun 2016

\section{Uji F}

Uji $\mathrm{F}$ diperlukan untuk menguji apakah model yang digunakan signifikan atau tidak, sehingga dapat dibuktikan apakah model tersebut dapat digunakan untuk memprediksi pengaruh variabel independen secara bersama-sama terhadap variabel dependen. Apabila probabilitas (F-statistic) lebih kecil dari sig $(0,05)$ maka model regresi linear berganda dapat dilanjutkan atau diterima. Berdasarkan tabel 7 diatas, diketahui bahwa probabilitas $F$-statistic yang diperoleh sebesar 0.032437 lebih kecil dari sig $(0,05)$. Ini membuktikan bahwa model regresi linear berganda diterima.

\section{Uji Koefisiensi Determinasi}

Uji ini dipakai untuk menguji goodness-fit dari model regresi dimana untuk mengukur seberapa jauh kemampuan model dalam menerangkan variasi variabel dependen maka dapat dilihat dari nilai $\mathrm{R}^{2}$. Setiap tambahan satu variabel independen, maka $\mathrm{R}^{2}$ akan meningkat. Oleh sebab itu untuk jumlah variabel yang lebih dari dua lebih baik menggunakan koefisiensi determinasi disesuaikan yaitu adjusted $R^{2}$ (Ghozali, 2009). Hasil estimasi pada tabel diatas, diketahui bahwa nilai adjusted $R^{2}$ yang diperoleh sebesar 0.045872. Hal ini menunjukan bahwa kontribusi variabel independen terhadap variabel dependen sebesar $\mathbf{4 , 6 \%}$ dan sebesar $\mathbf{9 5 , 4 \%}$ ditentukan oleh variabel lain yang tidak digunakan dalam penelitian ini.

\section{Uji Hipotesis (t-test)}

Uji t dipakai untuk mengetahui pengaruh variabel bebas terhadap variabel terikat dalam persamaan regresi secara parsial dengan mengasumsikan variabel lain dianggap konstan. Caranya dengan membandingkan antara nilai t yang dihasilkan dari perhitungan statistic dengan nilai $t_{\text {tabel. }}$ Untuk mengetahui nilai $t_{\text {hitung }}$ dapat dilihat melalui hasil uji regresi data. 
Berdasarkan hasil olahan data statistic pada tabel, dapat diketahui pengaruh antara variabel bebas terhadap variabel terikat secara parsial adalah sebagai berikut:

1) Hipotesis pertama dari penelitian ini yakni Financial Leverage berpengaruh positif terhadap initial return. Dari hasil pada tabel dapat diketahui bahwa koefisiensi $\beta$ financial leverage bernilai positif sebesar $\mathbf{0 . 0 2 3 3 8 5}$, nilai thitung $\mathbf{2 . 6 6 3 0 8 6}$ dan tingkat signifikansi $\mathbf{0 . 0 0 8 8}$. Hal ini membuktikan bahwa financial leverage (X1) berpengaruh positif dan signifikan terhadap initial return, sehingga dapat ditarik kesimpulkan bahwa hipotesis 1 diterima.

2) Hipotesis kedua dari penelitian ini yakni Profitabilitas berpengaruh negative dan signifikan terhadap initial return. Dari hasil pada tabel dapat diketahui bahwa koefisiensi $\beta$ profitabilitas bernilai negatif sebesar -0.194305 , nilai thitung $\mathbf{- 0 . 6 0 4 1 7 4}$ dan tingkat signifikansi $\mathbf{0 . 5 4 6 8}$. Hal ini membuktikan bahwa profitabilitas (X2) berpengaruh negatif dan tidak signifikan terhadap initial return, sehingga dapat ditarik kesimpulkan bahwa hipotesis 2 ditolak.

3) Hipotesis ketiga dari penelitian ini yakni Besaran Penawaran Saham berpengaruh negative dan signifikan terhadap initial return. Dari informasi pada tabel dapat diketahui bahwa koefisiensi $\beta$ besaran penawaran saham bernilai negative sebesar $\mathbf{- 0 . 1 9 1 5 4 6}$, nilai $t_{\text {hitung - }}$ 0.954163 dan tingkat signifikansi 0.3419. Hal ini membutkikan bahwa besaran penawaran saham (X3) berpengaruh negative dan tidak signifikan terhadap initial return, sehingga dapat ditarik kesimpulkan bahwa hipotesis 3 ditolak.

\section{Pembahasan \\ Pengaruh Financial Leverage terhadap Initial Return}

Uji hipotesis pertama dari penelitian ini menyebutkan bahwa financial leverage yang diukur dengan DER memiliki pengaruh positif dan signifikan terhadap initial return. Hasil ini sama dengan hasil penelitian Zirman dan Edfan Darlis (2013), Ayu Wahyusari (2013) dan Afifah Wulandari (2011) yang menyatakan bahwa financial leverage yang dihitung dengan DER memiliki pengaruh terhadap initial return. Namun berbeda dari penelitian yang dilakukan oleh Dewa Ayu Kristianti (2013), Eka Retnowati (2012), Lidya Soeryadjaya Witjaksono (2012) yang menyebutkan bahwa financial leverage tidak memiliki pengaruh terhadap initial return.

Hasil penelitian yang menunjukkan bahwa terdapat pengaruh antara financial leverage yang diukur dengan DER terhadap tingkat initial return yang terjadi saat IPO ini, menunjukkan bahwa investor mempertimbangkan nilai DER dalam keputusan penanaman modal yang dilakukannya. Hal tersebut membuktikan teori yang ada, bahwa dengan nilai DER yang tinggi ketidakpastian keberlangsungan hidup suatu perusahaan untuk masa depannya tinggi, hal ini akan berefek pada tingkat kepercayaan investor semakin menurun dan tingkat initial return semakin tinggi.

\section{Pengaruh Profitabilitas terhadap Initial Return}

Uji hipotesis kedua dari penelitian ini menyebutkan bahwa profitabilitas yang diukur dengan ROA tidak berpengaruh terhadap initial return. Hasil ini sejalan dengan penelitian Dewa Ayu Kristianti (2013), Rista Maya (2013) dan Lidya Soeryadjaya Witjaksono (2012) yang juga menyatakan bahwa profitabilitas tidak memiliki pengaruh terhadap initial return. Namun berkebalikan dengan penelitian yang dilakukan oleh Eka Retnowati tahun 2013, Afifah Wulandari (2011), dan Yurena Prastica (2012) yang menyatakan bahwa profitabilitas memiliki pengaruh terhadap tingkat initial return.

Hasil penelitian yang menunjukkan bahwa profitabilitas yang diukur dengan menggunakan ROA tidak memiliki pengaruh terhadap tingkat initial return yang terjadi pada saat IPO 
memperlihatkan investor berkeyakinan jika laporan keuangan perusahaan yang melakukan Initial Public Offering (IPO) di Bursa Efek Indonesia mengandung kecurangan dengan di mark up untuk menunjukkan kinerja yang lebih baik. Oleh karena itu investor tidak mempertimbangkan ROA yang disajikan dalam prospektus, tetapi cenderung merujuk pada ROA dalam beberapa tahun sebelum perusahaan tersebut melakukan IPO. Dengan demikian investor dapat mengetahui apakah laporan keuangan tersebut memang benar di mark-up atau tidak

\section{Pengaruh Besar Penawaran Saham terhadap Initial Return}

Uji hipotesis ketiga dari penelitian ini menyebutkan bahwa besaran penawaran saham yang diukur dengan persentase saham yang dijual ketika IPO memiliki pengaruh yang signifikan terhadap initial return. Hasil ini sejalan dengan penelitian Yasa (2008), dan Triani dan Nikmah (2006) yang juga menyatakan bahwa persentase saham yang ditawarkan tidak berpengaruh signifikan terhadap initial return. Namun berbeda dari penelitian yang dilakukan oleh Beatty (1989), Handayani (2008) dan Handono (2010) yang menyatakan adanya hubungan signifikan positif antara persentase saham yang ditawarkan dengan initial return.

Banyaknya persentase saham yang ditawarkan pada saat IPO bisa dipengaruhi oleh kebijakan dari perusahaan yang melakukan IPO, dengan adanya penurunan persentase kepemilikan dari pemegang saham lama adalah suatu konsekuensi yang harus diperhitungkan pada saat perusahaan memutuskan untuk melakukan IPO . Pemilik saham lama akan menyetujui keputusan IPO apabila mereka yakin bahwa saham perusahaan akan terjual pada harga yang cukup menguntungkan sehingga pemegang saham lama mau melepaskan atau mengurangi proporsi kepemilikan yang dimilikinya dalam perusahaan. Namun disisi lain jumlah saham yang ditawarkan pada saat IPO juga akan berpengaruh pada tingkat resiko dimasa yang akan datang, hal itu dikarenakan semakin banyak jumlah saham yang ditawarkan pada saat IPO, maka akan semakin tinggi pula resiko yang akan dihadapi pihak eksternal, seperti penjamin emisi. Sehingga dapat disimpulkan bahwa, semakin besar persentase saham yang ditawarkan kepada masyarakat maka resiko akan semakin besar dan harga penawaran perdana yang disepakati oleh emiten dan lembaga penjamin emisi juga akan semakin rendah, sehingga harga penawaran perdana yang rendah dapat mengakibatkan terjadinya initial return saham semakin meningkat.

\section{KESIMPULAN, KETERBATASAN DAN SARAN Kesimpulan}

Dari hasil penelitian dan pembahasan yang telah disajikan pada bab-bab sebelumnya, dapat ditarik kesimpulan sebagai berikut: (1) Financial Leverage memiliki berpengaruh positif dan signifikan terhadap Initial Return pada perusahaan yang IPO BEI selama periode 2011-2017. (2) Profitabilitas tidak berpengaruh terhadap Initial Return pada perusahaan yang IPO di BEI selama periode 2011-2017. (3) Besaran Penawaran Saham tidak berpengaruh terhadap Initial Return pada perusahaan yang IPO di BEI selama periode 2011-2017.

\section{Keterbatasan}

Nilai koefisien determinasi (Adjusted $\mathrm{R}^{2}$ ) dari penelitian ini relatif kecil atau rendah, yang artinya kemampuan variabel-variabel independen dalam penelitian ini dalam menjelaskan variasi variabel dependen sangat terbatas. Oleh sebab itu masih terdapat variabel-variabel lain yang berpengaruh pada initial return yang perlu untuk diteliti, seperti jenis industri, rata-rata kurs, reputasi penjamin emisi, likuiditas perusahaan, ukuran perusahaan serta indikator keuangan lainnya dan dari ketiga hipotesis yang diajukan dalam penelitian, hanya satu variabel saja yang 
bisa diterima yaitu variabel financial leverage. Hal ini mungkin disebabkan oleh jumlah sampel yang masih kurang (sebanyak 127 perusahaan sampel) dikarenakan beberapa perusahaan yang memiliki data yang tidak lengkap atau periode penelitian yang masih singkat, yaitu dari tahun 2011-2017.

\section{Saran}

Dari hasil penelitian ini disarankan agar manajemen perusahaan dapat memberikan perhatian khusus pada terjadinya fenomena initial return dikarenakan apabila terjadi underpricing, maka perusahaan tidak akan mendapat dana yang maksimum dari aktivitas IPO. Emiten sangat berkepentingan untuk menetapkan harga saham IPO yang maksimum untuk memaksimalkan dana yang dihimpun. Sebagai pihak yang membutuhkan dana, perusahaan sebaiknya berusaha memperoleh harga perdana yang tinggi.

Bagi para calon investor yang ingin melakukan investasi di pasar perdana harus mempertimbangkan informasi lain yang dapat dilihat dalam prospektus keuangan untuk memperkirakan saham yang tidak akan mengalami underpricing sehingga dapat digunakan dalam pengambilan keputusan investasi sehingga investor akan mendapatkan keuntungan dalam bentuk pengembalian yang optimal atau return yang sesuai dengan yang diharapkan.

Untuk peneliti selanjutnya yang akan meneliti hal yang sama, disarankan untuk menambah variabel-variabel lain yang diduga memiliki hubungan yang signifikan dengan initial return atau variabel yang lebih menunjukkan hubungan dengan initial return ini, baik itu variabel yang memuat informasi keuangan maupun variabel lain yang menyatakan informasi dari aspek lain. Beberapa di antaranya adalah veriabel likuiditas, persentase saham yang ditawarkan, ukuran perusahaan, reputasi underwriter, reputasi auditor, jenis industri, dan lain-lain sebagai variabel independen atau variabel yang mempengaruhi terjadinya initial return. Dan sebaiknya jenis pengukuran yang digunakan adalah sama agar rentangan data tidak begitu jauh atau menghindari data yang bias.

\section{DAFTAR PUSTAKA}

Ang, Robert. (1997). Buku Pintar Pasar Modal Indonesia. Indonesia: Mediasoft

Apriliani, T dan Hikmah. (2006). Reputasi Penjamin Emisi, Reputasi Auditor, Persentase Penjamin Emisi, Ukuran Perusahaan yang Melakukan Kebijakan Initial Public Offering (IPO) di Indonesia. Symposium Nasional Akuntansi X.

Chen, Su. (2011). Underpricing and Long-Run Performance Of Chinese IPOs: The Role Of Underwriter Reputation. Financial markert Research Portf Manag, 25, 53-74.

Daljono. (2000). Analisis Faktor-Faktor yang Mempengaruhi Initial Return Saham yang Listing di Bursa Efek Jakarta (Tahun 1990-1997). Symposium Nasional Akuntansi III: Solo

Darmadji, T. dan Hendy M. F. (2012). Pasar Modal di Indonesia: Pendekatan Tanya Jawab. Edisi 3. Jakarta: Salemba Empat.

Fahmi, I. (2011). Analisis Kinerja Keuangan. Bandung:Alfabeta

Fakhruddin, H. M. F. (2008). Go Public: Strategi Pendanaan dan Peningkatan Nilai Perusahaan. Jakarta: PT Gramedia.

Febriani, L. (2013). Pengaruh Likuiditas, Leverage dan Profitabilitas Terhadap Initial Return Pada Perusahaan yang Melakukan Initial Public Offering. E-Journal:Universitas Negeri Padang.

Ghozali, I. (2011). Aplikasi Analisis Multivariate dengan Program SPSS. Semarang: Badan Penerbit Universitas Diponegoro. 
Handayani, S. R. (2008). Analisis Faktor-Faktor yang Mempengaruhi Underpricing pada Penawaran Umum Perdana. Tesis. Program studi Magister Manajemen Universitas Diponegoro Semarang.

Harahap, S. S. (2010). Analisis Kritis Atas Laporan Keuangan. Jakarta: Rajawali Pers. Hartono, J. (2002). Teori Portofolio dan Analisis Investasi Edisi Ketiga. Yogyakarta. BPFE.

Husnan, S. (2001). Dasar-Dasar Teori Portofolio dan Analisis Sekuritas. Yogyakarta: UPP AMP YKPN.

Kasmir. (2008). Analisis Laporan Keuangan. Jakarta: PT. RajaGrafindo Persada.

Kim, A. K. (2001). The Underpricing of seasoned Equity Offering:1983-1998. Assistant Profesor of finance.

Kim, K. dan Lee. (1995). Motives For Going Public And Underpricing New Evidence From Korea. The International Journal Of Accounting, 29.

Marshall, B. B. (2004). The Effect Of Firm Financial Characteristics And The Availability Of Alternative Finance On IPO Underpricing. Journal Os Economic and Finance, 28(1).

Retnowati, E. (2013). Penyebab Underpricing pada Penawaran Saham Perdana di Indonesia. Accounting Analysis Journal 2: Universitas Negeri Semarang.

Risqi, I. A. (2013). Analisis Faktor-Faktor yang Mempengaruhi Underpricing ketika Initial Public Offering (IPO) di Bursa Efek Indonesia. Diponegoro journal of Accounting, 2(3), $1-7$.

Soewardjono. (2005). Teori Akuntansi dan Perekayasaan Pelaporan Keuangan. Yogyakarta: BPFE.

Subramanyam, J. J. W. (2010). Analisis Laporan Keuangan Jilid I. Jakarta: Salemba Empat.

Subramanyam, J. J. W. (2010). Analisis Laporan Keuangan Jilid II. Jakarta: Salemba Empat

Suyatmin dan Sujadi. (2006). Analisis Faktor-Faktor yang Mempengaruhi Underpricing Pada Penawaran Umum Perdana di Bursa Efek Jakarta. BENEFIT, 10(1), 11-32.

Syamsuddin, L. (2001). Manajemen Keuangan Perusahaan. Jakarta: Raja Grafindo Persada.

Tandelilin, E. (2010). Portofolio dan Investasi. Teori dan Aplikasi. Yogyakarta: Kanisius.

Undang-Undang Republik Indonesia Nomor 8 Tahun 1995 Tentang Pasar Modal.

Witjaksono, L.S. (2012). Analisis Faktor-Faktor Keuangan yang Mempengaruhi Fenomena Underpricing pada Perusahaan Sektor Keuangan yang Terdaftar Di Bursa Efek Indonesia 2002-2010, Berkala Ilmiah Mahasiswa Auntansi, 1(1).

Wulandari, A. (2011). Analisis Faktor-Faktor yang Mempengaruhi Underpricing pada Penawaran umum Perdana (IPO) (Studi Kasus pada Perusahaan Go Public yang Terdaftar di Bursa Efek Indonesia tahun 2006-2010). Jurnal Ilmiah: Universitas Diponegoro.

Yasa, G. W. (2002). Penyebab Underpricing pada Penawaran Saham Perdana di Bursa Efek Jakarta. Skripsi. Fakultas Ekonomi Universitas Udayana.

Yurena Prastica. (2012). Faktor-Faktor yang Mempengaruhi Tingkat Underpricing pada Saat Penawaran Umum Saham Perdana. Jurnal Ilmiah Mahasiswa Akuntansi, 1(2).

Zirman dan Darlis, E. (2013). Pengaruh Informasi Akuntansi Dan Non Akuntansi Terhadap Kecenderungan Underpricing: Studi Pada Perusahaan Yang Melakukan Initial Public Offering (IPO) di Bursa Efek Indonesia. Skripsi. Fakultas Ekonomi Universitas Riau Kampus Bina Widya. 